\title{
Analyzing Biographies of Foreign-born Academics in Slo- vakia: Why Highly Skilled Employees Decide to Choose a Peripheral Country
}

\author{
Kamil Łuczaj ${ }^{1}$ \\ University of Information Technology and Management, Rzeszow
}

\begin{abstract}
Analyzing Biographies of Foreign-born Academics in Slovakia: Why Highly Skilled Employees Decide to Choose a Peripheral Country. This paper summarizes findings from qualitative research conducted in Slovakia in early 2018. One of the main research questions was related to factors attracting foreign-born academics to Slovak higher education institutions. This data supplements limited knowledge derived from the official statistics. Using individual in-depth interviews (IDI), six types of foreign-born academics were distinguished: family-tied academics, commuters, socioeconomic migrants, transnational scholars, local enthusiasts, and last resort scholars. The paper includes a detailed characteristic of each category supported by extensive excerpts from the interviews. It facilitates a discussion regarding another dimension of the distinction between global academic centers and peripheries.

Sociológia 2019, Vol. 51 (No. 3: 250-271)

https://doi.org/10.31577/sociologia.2019.51.3.12
\end{abstract}

Key words: Academic migration; foreign-born scholars; Slovakia, Slovak academic system; higher education in Central Europe

\section{Introduction: Highly skilled migrants in Slovakia}

As is reflected in existing sociological research, Slovakia, like other Central European countries, has traditionally been a country of emigration (see e.g. Lášticová 2014; Blazek 2015; Bahna 2018). At the same time there is a body of knowledge related to socioeconomic migrants to Slovakia (Hlinčíková 2010; Sekulová 2010). The situation of highly-skilled academic migrants who decide to move to Slovakia remains comparatively unsearched. Insights into the situation of academics have certain policy implications discussed throughout the paper. If the internalization of academia is a true goal of Slovak authorities, then careful analysis of the biographies of those who have already decided to stay seems to be necessary in order to gain the in-depth understanding needed to plan comprehensive policies. Moreover, tendencies such as low level of internationalization and high pressure for improvement discovered in other Central European countries (Mucha - Łuczaj 2017) - are present also in Slovakia as its universities aspire to keep up with western universities, though they are usually underfinanced.

There is as yet no consensus regarding what a highly skilled-migrant is. The most usual elements of definition include level of education, the type of job

\footnotetext{
1 Address: Kamil Łuczaj, PhD., University of Information Technology and Management, Rzeszow, Poland. E-mail: kluczaj@wsiz.rzeszow.pl
} 
(occupation), or salary, with the common denominator being the willingness of highly skilled workers to "maximize the return on their investment in education and/or training by moving around in search of the highest paid or most rewarding employment" (Iredale 2016). According to OECD, highly-skilled migrants include highly skilled specialists, independent executives, and senior managers, specialized technicians or tradespersons, investors, business persons, "keyworkers" and sub-contract workers (Iredale 2001: 8). In general terms, all those individuals can be divided into business-oriented people (see Piekut 2013) and academics (see Skachkova 2007; Alberts 2008; Kreber - Hounsel 2014; Munene 2014). Academic studies reported that most of the problems common to both groups include limited interactions with colleagues and other local people, the language barrier, limited research funding, and cultural differences.

Slovakia has been chosen as an exemplary peripheral country. "Peripheral", in Immanuel Wallerstein's (2007) world-systems theory is a descriptive, nonevaluative term referring to those countries that cannot directly benefit from the global circulation of knowledge. From this perspective, peripheral countries act as reservoirs of a cheap workforce. The hegemony of western academic systems has been thoroughly investigated in the context of original Wallersteinian ideas elsewhere (Alatas 2003; Rodriguez 2014; Connell et al. 2017), so here it suffices to say that one epiphenomenon of "academic imperialism" is that non-central countries are understudied, even though they are successful enough to attract some scholars. This paper tries to fill the gap regarding academic employees outside of global academic centers. One of the most salient discoveries is that Iredale's definition presented above is not necessarily helpful in describing the life paths of foreign-born academics in semi-peripheries. As it turns out, they are not always motivated by the sole maximization of their educational investment but are often driven by other factors unrelated to remuneration or better working conditions. Unfortunately for the policymakers, none of these can be easily manipulated.

\section{Foreign-born academics in Slovakia: An overview}

Slovakia became a member of the EU in 2004 and now its labor market is open to candidates from other member countries. In the case of third-country nationals formalities are still complex, but there is a loophole in a form of the EU Blue Card, i.e. a work permit that facilitates the inflow of educated workers to Europe. Interestingly, in 2016 Slovakia issued only four Blue Cards (OECD 2017: 92). Moreover, the Foreigners' Police Department has quite a negative reputation (see Minarechová 2017), with the most reported problems being long wait times, poor or non-existing English skills among its employees, and unnecessarily complicated procedures. Those circumstances are experienced as 
hindrances rather than help by the skilled workers during the very beginning of their stay in Slovakia.

According to the official statistics ${ }^{2}$ the total number of foreigners in the Slovak academic system in February 2018 was 861 (which translates into 5.9 percent of all academic staff). Most often they come from the neighboring countries: Czech Republic $(n=197)$, Hungary $(n=71)$, Poland $(n=55)$, and Ukraine ( $\mathrm{n}=37)$. Women constitute approximately one third of this number (37 percent, or 319 people). Nevertheless, in Slovakia there is a relatively high population of academics from the western countries (e.g. 16 academics from the US, 14 from France etc.). Unfortunately, that is almost all we can learn from the official statistics. A qualitative study was a necessary step to examine this stratum in detail in order to answer the question about motivations and life trajectories of foreign-born academics employed in Slovakia.

\section{Methodology and sampling}

The main method employed in this study was qualitative individual in-depth interviews (IDI). The empirical material comprises 40 interviews with foreignborn academics who worked at a Slovak higher education institution or an Institute of Slovak Academy of Sciences (SAS) ${ }^{3}$. Every interview had the form of an individual encounter with a selected scholar. Usually the interview language was English but in rare cases a part of the interview was conducted in other European languages spoken both by the interviewer and interviewee ${ }^{4}$. All the interviews were conducted in early 2018 based on an interview guide with 70 detailed questions related to the current position held in Slovakia, the biography, research and achievements, motivations, relations with the country of origin, how Slovakia is perceived as a country to live in, Slovak academia, the interviewees' own identity, and their plans for the future. The interviews have been thematically analyzed (Guest et al. 2012). In this paper, I draw upon codes and themes related to motivation factors and the adjustment to the new academic and social environment. This methodological choice allowed me to gain rich insight, on the one hand, but on the other hand, makes it impossible to provide any quantitative measurements. Every time I refer to hard numbers I do it in order to show the proportion within the sample; any conclusion can therefore not be extrapolated to the general population. The main aim of this paper was to create a typology of foreign-born scholars in Slovakia and

\footnotetext{
2 Register zamestnancov vysokých škôl (2018).

3 The operational definition of an academic embraces those individuals who are formally employed by a Slovak higher educational institution (including language instructors; 5 cases out of a total of 40 interviews).

4 Those parts were proofread by a native speaker of English. The remaining quotations come from interviews conducted originally in English with native and non-native English speakers. For this reason, some of them contain grammar errors and infelicities. All particular details (e.g. cities, universities, names) were removed.
} 
describe their motivations. That task would be impossible without excerpts from interviews and their qualitative interpretations.

The interviews were focused on the development of an academic career. For that reason, the empirical material contains large portions of biographical narratives, which are treated as "lived experience" - the subjective perception of life events. In order to analyze the material, I was looking for "biographical action schemes", "institutionalized schedules for organizing biographies", "biographical trajectories" as well as "biographical metamorphoses" as defined by Fritz Schütze (2014: 255). Each narrative contained the account of individually planned social actions (action schemes) and structural factors driving the careers of the informants. It turned out that the latter were more relevant and thus more often discussed than the planned actions. This fact itself suggests that academic migration to Slovakia is rather a combination of contingent factors than an autonomous decision.

The sample was diversified by gender ( 26 male and 14 female), nationality (various European and non-European countries) ${ }^{5}$, field of expertise (29 from humanities and social sciences, henceforth: HSS and 11 from science, technology, engineering, and mathematics, henceforth: STEM), and seniority (from 2 to 39 years after their $\mathrm{PhD}$ graduation) - professors, associate professors, assistant professors and other academic instructors or employees of $\mathrm{SAV}^{6}$. Eighteen interviewees were involved both in teaching and research, 15 only in research and the remaining 7 only in teaching. Twenty-one interviewees worked in Bratislava and 19 in other Slovak cities, however it is worth noting that some of the latter also lived in Bratislava and commuted to work.

\section{The typology}

In what follows, based on empirical research, I propose a typology of foreignborn scholars employed in Slovakia. Some methodological implications of this focus need to be made explicit before I am able to present empirical findings. In social sciences, typology is usually perceived as a heuristic tool useful for explaining social systems. Typologies in sociology can be divided into two broad types: the existential type, i.e. developed by participants in social systems, and the constructed type, i.e. formulated for purposes of analysis of social phenomena by a social scientist (McKinney 1969). As John C. McKinney (1969: 10) noted long ago, "It is true that typology, in its existential sense, is as old as society, and in its constructed sense, as old as scientific reflection on society." Existential types, as the extractions of the folk

\footnotetext{
5 For the sake of my interviewees' privacy I refrain from divulging particular data regarding their places of origin, as those may ultimately be utilized to identify them. Twenty-one interviewees came from Central and Eastern Europe and 19 from other countries.

${ }^{6}$ Eight interviewees did not have a PhD title.
} 
methods or modes of thought from social action, are especially suitable for qualitative research; nevertheless, it is rather unusual that interviewees classify themselves as belonging to a specific collectivity. More often, they provide the researcher with useful labels. For instance, one of western interviewees labeled himself as a "refugee from that system," referring to everyday life in his home country (Male, Westerner, HSS, INT19). The categories are not constructed based on such labels but on the basis of full narratives. Due to the breadth and depth of the interviews, I was able to construct those categories and saturate them with data. In doing so, I assured that the typology is theoretically grounded. Some authors propose that an empirical base allows us to construct a "taxonomy" which, unlike a standard typology, is empirically grounded (Smith 2002: 381). What follows is thus a constructed typology/taxonomy drawn on the basis of 40 qualitative in-depth interviews with scholars employed in Slovakia.

\section{Family-tied academics}

A family situation often has a major influence on a migration decision (Raghuram 2004). Academic migration is not an exception. Some foreign-born scholars decide to migrate because there are sound family reasons encouraging their decision. Those can be referred to as "family-tied academics", an umbrella term for the individuals who decided to move abroad along with a partner, migrated during childhood, or have other family-related reasons. This term is obviously rooted in postmodern definitions of a family, describing it as "a group of people that love and care for each other" (Stacey 1998: 270). The experience of my informants shows that it was very common for migration to Slovakia to be closely related to family matters, namely a relationship with a Slovak. Many interviewees met their partner and decided to move to Slovakia not for professional reasons but in order to be together with the partner ${ }^{7}$. The "transnationalization of partnership" was a number one cause and many interviewees were well aware of it.

Well, as I said on the written survey, like most men living in Slovakia, they live there because they were married to Slovak (Male, Westerner, HSS, INT12) ${ }^{8}$.

I came to Slovakia in [year]. Before that I was a student in [home country] and I met a girl from Slovakia. And as a lot of [compatriots] in Slovakia I fell in love with this girl (Male, Westerner, HSS, INT11).

\footnotetext{
7 Interviewees often highlighted how their marital status (being either single or divorced) helped them to be mobile: "I'm single. It's easy to move" (Female, Easterner, HSS, INT15); "I was a teacher just as here. I've been recently divorced. So, you know. I wasn't really incumbent by family anymore" (Male, Westerner, HSS, INT17).

8 Every interview ID contains: Gender/Country Group/Area of Specialisation (HSS or STEM)/Number.
} 
I married a Slovak woman. (...) We worked for the same person when we were doing post-doc studies in [country]. She decided she wanted to return to Slovakia and as I didn't have anything better to do with myself at that point I came too (Male, Westerner, STEM, INT31).

I meet a Slovak, who is a very nice man, spouse and a father of our two children. We meet during a summer camp (...) It was a joint venture of [country] and Czechoslovakia (...) Then I took a maternity leave and started a language training (Female, Central Europe, STEM, INT13).

\section{What was the main reason for coming to Slovakia?}

Love [laughing]. (...) The girl who brought me here was the mother of my first daughter. (...) We met in [home country] in my village (...) At that time she was a student, but we both were to finish it. We were master students (Male, Westerner, STEM, INT35).

As we have seen, many encounters took place abroad. Moreover, often before they decided to move to Slovakia, these mixed couples spent some time abroad - in the country of the second partner's origin or a third country. A common option among such couples was ultimately to move back to Slovakia, which could be due to the fact that Slovak citizens had some difficulty finding an appropriate job abroad:

I mean I had a job at the [place] obviously, and I knew there wasn't going to be a career for me but [partner] found it very difficult to find a work in [city].

\section{As a foreigner?}

Yes, there was a combination of things. Firstly, there was a financial crisis going on at the time so there were fewer jobs anyway and foreigners when they move to [home country] the generally have to retrain at a local school in order to be seriously considered by the employer (...) And she had a languages degree, which in [his home country] is pretty pointless. Because nobody really cares if you can speak [language] for instance. It's more a country suited for people with technical... opportunities and [partner] had a lot of friends, language graduates from Slovakia, who had really good jobs here at multinational companies. She just didn't want to be a waitress anymore, which I totally understand. So we decided to move and I think it's been a great decision (Male, Westerner, HSS, INT3).

\section{So why did you decide to come to Slovakia?}

Because you know... [academic discipline] you can do research everywhere [laughing], and to be a [occupation] you need to know [local language] very well. She knew very well the language but for everything it was better in 
Slovakia. In [my country] it was more complicated. (...) The EU makes everything easy... It's not like that. I think that there is always some chauvinist protection. And a [occupation] from Slovakia in [country]? Yhmmm? Slovakia, Slovenia, Czechoslovakia? You know [laughing] (Male, Westerner, STEM, INT35)

As it was clearly demonstrated in the first of the two excerpts above, the decision to move to Slovakia was also often related to economic crisis, most notably the one in 2008. This was a recurring topic in the case of people from countries other than Eastern Europe. In those narratives another common element was visible: foreign-born academics were often motivated by the need to take care of their partners' ageing parents.

We were talking about the possibility to move to [non-European] country (...) I have friends living there, working at the university. (...) [Husband] told me that his parents live alone here so he wouldn't like to live so far. On the other hand, I like to live in Europe (Female, Other countries, STEM, INT10).

And yet we had another reason to come here. My mother in-law died in [year] so... my wife wanted to look after her father, essentially. My wife is originally from here so she had a lot of connections, a lot of reasons to... (Male, Westerner, HSS, INT12).

The decision to choose Slovakia over the other partner's home country was easier for all the Western interviewees (including non-Slovak-speaking), as they all agreed that it was easy to find a job in Slovakia. Some of them started as language instructors in language schools and then transferred to academia.

It was a paradox but I had more opportunities in Slovakia than in [home country]. Because as a [nationality] you can work in society, you know, they always need foreign people. And I had an offer from one primary school in [city] and I started work there. It was better, we were together [with a partner] (Male, Westerner, HSS, INT11).

I worked here and I worked at private language schools. So... you know. Multiple job. It has never been difficult for me to get a work here, as an English teacher, so I'm not worried about... I can work at language schools, high schools, and all around. (Male, Westerner, HSS, INT12).

The ease of finding a job was not limited to people in HSS - scientists also reported a strong need for qualified, foreign-born staff in Slovakia. This is very different from Western core countries, where competition is usually very high (Maximova-Mentzoni et al. 2016). 


\section{And how did you find your first job in Slovakia?}

It was pretty easy. I was positively surprised about that. Maybe I was lucky, I don't know. So I sent many $C V$ around the institutions, universities and some replied me and I chose one option that was [institution] in Bratislava (Male, Westerner, STEM, INT35).

So why did you decide to go to Slovakia? Because it is not typical for [nationality] to be in Slovakia.

I won't say so, because currently the work market changes a lot (...) Slovakia is opening many positions even for [nation]. (...) I would say that it is pretty common to move nowadays within the borders of Europe. And especially for the [nation] because our work market is not so good at the moment. We have a really high unemployment (...) The problem is that they have really high retirement age and this is not helping the young to enter the work market. (...) It's easier to enter the job market [in Slovakia] (Male, Westerner, STEM, INT30).

It is noteworthy that family-motivated migration is characteristic especially of the less developed eastern part of Slovakia where family was considered one of the most significant pull factors. Foreigners in Eastern Slovakia did not even consider Bratislava as a possible destination, because one of the purposes of their return was to help older members of a family. By the same token, if Eastern Slovakia is a national periphery, then Slovakia is certainly a periphery in a global system of knowledge production. Western research on academic migration shows that family factors are among the least important factors behind the decision to work abroad (Franzoni et al. 2012). Unlike the US, in Slovakia, family or partnership matters were the number one motivation to work in that country. Number two was another phenomenon barely observable in Western Europe and America.

\section{Commuters}

This category is typical for academics from neighboring countries. International research project Changing Academic Profession demonstrated that the share of international commuters in 19 different countries was only one percent (Rostan - Höhle 2014: 84), whereas according to my interviewees in Slovakia, the commuting phenomenon there is far more widespread. Commuting academics usually do not spend much time in Slovakia, as their home is located outside the country, but they are able to go back and forth a couple of times each month. They are usually motivated by financial rewards. Slovak academic institutions, in turn, are required to employ a certain number of Professors (acting as "guarantees") in each department in order to gain 
accreditation ${ }^{9}$. They therefore try to hire professors from Poland, Czech Republic, Hungary, Ukraine, or Austria. One of the interviewees revealed that being from a western country was seen as an advantage by Slovak employers: "They preferred to have someone in the institute who's not from Hungary, nor from Poland, nor from Czech Republic." ${ }^{10}$ Scholars from those neighboring countries more often agree to work in Slovakia and are thus not perceived as being exceptional compared to employees from, for example, Austria - even though commuting from Austria or Eastern parts of Germany can be easier than commuting from Poland.

In general, commuters usually emphasized that going back and forth from their country to Slovakia is not very problematic and is fairly inexpensive:

It's two and a half hours by train. The ticket is about 15 EUR (Male, Central Europe, HSS, INT36).

The road is good, except for the section between [city] and [city] but it's changing for the better. I have ten years' experience and I can say that travel time is getting shorter and shorter and the road better and better (...) It's faster than driving to [capital of home country] (Male, Central Europe, HSS, INT2).

\section{How much time do you spend in Slovakia?}

1-2 days but from the morning to the evening. I go by train. It's quick. It takes me one hour from here to [city] and then I wait half an hour and it takes me another 25 minutes do go [to the final destination]. It's a very good connection.

\section{And how much do you pay for a return journey?}

For the moment, it's 17 or 18 Euros. But it's cheap. It's really cheap (Female, Westerner, HSS, INT34).

Inexpensive commuting is crucial because salaries in Slovak academia, and elsewhere in Central and Eastern Europe (CEE), are low compared to the western countries (MORE2 2010). In 2017, the average monthly gross wage of teachers at public Slovak universities was below 1500 EUR (OZPS 2017). In contrast, an assistant professor in Vienna earns as much as 2800 EUR and a full professor, 5000 EUR $^{11}$. From this perspective, Slovak offers can be seriously considered only as a second job next to an already existing primary job. Fast

\footnotetext{
${ }^{9}$ In the Slovak academic system the university must employ a certain number of professors for each study programs who "guarantees" the teaching quality.

10 For the sake of anonymity, the ID of this interview was removed.

${ }^{11}$ Source: https://personalwesen.univie.ac.at/en/jobs-recruiting/job-center/salary-scheme/ [access: 5 Oct 2018]
} 
and inexpensive transit makes those offers more profitable for academic commuters.

\section{Socioeconomic migrants}

At first glance, the existence of this category is paradoxical. Due to low salaries, many national and foreign-born scholars held multiple positions in order to make a decent living. Official statistics indicate that, depending on the faculty, an average percentage of employees with more than one affiliation is around seven percent, but there are organizational units in which almost 30 or 40 percent of their employees are also affiliated elsewhere ${ }^{12}$. This situation is typical for the entirety of Central Europe, where scholars hold more than one position - within or outside of academia - out of economic necessity.

Considering that salaries in Slovak academia are usually low, it is a relevant question if economic motivations are at all among pull factors for academics coming to Slovak HE institutions. Socioeconomic migrants (Zommers McDonald 2012), in the Slovak reality, are the ones interested in better salaries but also in better conditions - or at least work environments not suffering from the omnipresent corruption. They all know that Slovakia is not perfect but they expressed that it was still way better than their home country. In this sense, they are "socioeconomic refugees," seeking better pay and a better life abroad.

Those people came to Slovakia for economic and social reasons, seeking better working conditions within the EU. They increase their socioeconomic status - understood in a classical way as a mix of economic situation and occupational prestige (see e.g. Wright 1997). Moving to Slovakia doesn't change much in their relation to their colleagues - in most of the cases they were elites in each country but an economic status increased after the migration. In this case Slovakia is an attractive country as such, because it allows Easterners to earn up to four times their last paycheck, but also with European labor laws, freedom of movement, and other benefits. A good example of status migrant is Sonia (INT15), an immigrant from the former USSR. Her story shows that working conditions in Slovakia are much better and more stable than in some eastern countries. The essential part of the interview with Sonia comprised a detailed description of the poor academic conditions in her home country. The major problem was the salary - her monthly income amounted to a maximum of the equivalent of 300 EUR, putting it together via diverse sources of income: the university contract (around 250 EUR net) and extra classes (50-100 EUR, depending on the number of hours). Moreover, out of this salary she had to pay for various workrelated expenses, including conference fees. "In [home country], I was paying

12 Source: Register zamestnancov vysokých škôl (2018). 
for everything. My parents were supporting me," she admitted (Female, Easterner, HSS, INT15).

Sonia's complaints were also related to the work space. The common room for faculty members was continually overcrowded, occupied by as many as ten people simultaneously. It was equipped with just two computers: one for the secretary and the other one for all the remaining employees. The entire institute lacked space. In order to deal with the problem, they had to hold classes in shifts: newer students took classes in the mornings while older students started at 1PM and ended at 7PM. Taking all of this into account, it is no surprise that Sonia was satisfied with her Slovak workspace and salary (at least for now, since she doesn't have to provide for her family). She transferred from the best university in her home country to an average institution in Slovakia, but in her opinion it was still worth it, given the aforementioned conditions. "Fewer hours, better payment; fewer students in groups. It eased my way of life," she summarized.

In this sense, there were many "Sonias" in the sample. One of them, Katarina, said that another problem was economic instability, one more social factor behind the migration:

We have a crisis right now in [home country]. First of all, [local currency] collapsed. (...) But before the collapse, I could get something like 500 Euros and with additional teaching, I tell you in dollars, I could get 1000 dollars a month as well. Netto. It was [year].

So it's comparable to Slovak salary.

But now three times it fall. So now you can divide 1000 into 3 and you'll get 300 (Female, Easterner, HSS, INT24).

\section{Transnational scholars}

This category embraces mainly academics who came to Slovakia through the Marie Curie scholarship programme (SASPRO). They come from different parts of the world and usually have not only an outstanding publication track but also vast international experience. They have worked in different academic cultures and publish internationally, usually among the conditions for being referred to as transnational scholars (see e.g. Lau 2009; Tilley - Taylor 2014).

Due to SASPRO scheme rules, their salaries and working conditions are good. Adam (INT6), a Central European, who had previously been lecturing in global academic centers, is an example of this type. Maria (INT39) and Viktor (INT36) also represent people building bridges with other academic systems without fully immersing in Slovak academic reality, thereby treating their stay in Slovakia as a stepping stone in their career path. 
The first step was to contact the group. To get this position, one had to find a group willing to accept this candidate. We had no cooperation with any group in Slovakia, so I browsed websites and publications from Slovakia, and I found that the group here, in the institute, has several publications that are very close to what I would like to do here. I contacted the head of this group who liked very much the idea of me applying for this project (Male, Central Europe, STEM, INT6).

You do not have a lot to lose when you apply for this. So the [scholarship scheme] was not particularly demanding to put together as you may know. (...) I actually thought that this would be, you know, a great opportunity to spend some time in [Slovak city] (Male, Easterner, HSS, INT36).

So this is how it happened and this was by accident, because I was looking at the [scholarship scheme] website on the [portal]. And I have to be honest before coming I knew nothing about [city]. I lived in [western city] for many years. I worked there. I was a lecturer there. So, I still consider, you know, like home is very difficult to describe, home when I'm here is [western city] but also [home town] (Female, Other countries, HSS, INT39).

A distinctive type of transnational academic is the international university language teacher (Xu 2014; Pauwels 2014). Their role is usually restricted to teaching a language or language and culture. They have no academic ambitions, nor academic degree but want to teach internationally. They often benefit from the fact they are native speakers. Often, due to low salaries, they have to take several jobs. A paradigmatic example is Simon (INT17), an English native-speaker who came to Slovakia a couple of years prior to the interview. The life trajectory of Jean (INT11) was similar, but in his case the relationship with a Slovak was also an important factor in his biography.

Just that I was interested in international teaching. I was working already in [home country].

(...)

\section{But why Slovakia?}

That's really simple. Vacancy was here so I came here.

And how did you learn about the vacancy?

Well, there was an international job board (Male, Westerner, HSS, INT17).

I found one European Voluntary Service in [city] and I... didn't teach French before. I were there one year. I learned Slovak language. I wanted to stay in 
Slovakia. So I came to [city] and I asked [an organization] if they can offer me some work. And I'm still here (Male, HSS, Westerner, INT11).

This type of academic employee is present in every academic system. Peripheries are not different from global academic centers by any means. Peripheries may be slightly more exotic, but interviewees from this category were simply interested in international teaching. The next category, enthusiasts, also exists both in centers and peripheries but it plays a different role in each context.

\section{Local enthusiasts}

Enthusiasts are those migrants who prefer to live and work in a given country. In the migration literature, they are denoted by many notions: Tremblay et al.'s (2014) academics motivated by "political and social factors", Siegerts's (2011) "Germanophiles", Vuin et al.'s (2016) "amenity migrants", or Benson and O'Reilly's (2009) "lifestyle migrants" - to mention only a few examples. Slovak "enthusiasts" can be divided into those who are interested mainly in Slovakia or Central Europe (and have those regions as the geographical focus of their research) and those who came here out of curiosity to learn about a different region ${ }^{13}$. The following excerpt from an interview with a western female scholar named Theresa ${ }^{14}$ is especially instructive with respect to the first type.

The simple reason why I came here is that my major research focus has been [topic related to Slovak culture]. So clearly it makes sense in research terms to me to be here. And also in terms of getting grants I fit better into a team here, because if you're doing a Slovak case study, it makes more sense to do it in Slovakia. But having a [Westerner] on the team is also helpful and I actually having an outside view of the country helps (Female, Westerner, HSS, INT9).

Another Westerner, Eric (INT12), was attracted by the specificity of Slovakia. The most striking element of this excerpt is that his original motivation was pure curiosity, but he also explains why it has been worth relocating to Slovakia. Eric is a western European teaching his mother tongue in a classroom setting, and he came to Slovakia to verify the image of Eastern Europe he knew from the movies. He had previous international experience and - while abroad - he found that there was a position in Slovakia. He started as a high school teacher and subsequently transferred to academia.

\footnotetext{
${ }^{13}$ For this reason, international language teachers are often the enthusiasts motivated by curiosity.

14 All the names have been changed.
} 
I had a picture about Eastern Europe, romantic picture, so I decided to go to Slovakia (...) When I was younger in my 20s... I had an image of Eastern Europe shown in films by Kusturica, or Tony Gatlif. So something wide. Something different.

\section{And you liked it? \\ Yes, certainly. I was in a group in [home country]. We were alternative people [associated] with theatre (...) So there was Balkan music, cigan music, so it was an important part of alternative culture [in the home country]. (...) When I was younger I had this romantic ideal of Central and Eastern countries and I wanted to destroy it. (...) I just told to myself that I wanted to make a tabula rasa and to be realistic so I went there to see (Male, Westerner, HSS, INT16).}

The experience of this interviewee is close to what has been referred to as "lifestyle migrant". Those are usually "relatively affluent individuals of all ages, moving either part-time or full-time to places that, for various reasons, signify, for the migrant, a better quality of life" (Benson - O'Reilly 2009: 609). In Eric's case, the pull factor that lies at the root of his migration and the framing of his daily life was cultural curiosity (Benson 2016: 2). His example shows that academic migration can be culturally motivated, as opposed to the more economic motivation of "last resort scholars" and "socioeconomic migrants". This cultural motivation is specific to work in academia, which is often "a calling" as defined in the classical text of Max Weber (Weber 2004; Myers 2004). Such a vocation can be easily opposed to a regular nine-to-five job, where material factors play a crucial role and a sense of mission or calling can be absent. The problem with peripheral countries is that they are usually unable to attract STEM scholars looking for reputable universities and research centers or better working conditions (remuneration, equipment, office space, etc.). Those in HSS can be interested in social or cultural phenomena unavailable elsewhere but lifestyle migration to Slovakia within STEM is virtually non-existent. The only exceptions were scholars attracted by special scholarship schemes, who often happen to be "transnational scholars", discussed above.

\section{Last-resort scholars}

The phrase "unemployed PhD" might have sounded like an oxymoron a couple of decades ago, yet nowadays universities train more people than they can actually employ, which makes academic markets more competitive than ever (Arbesman - Wilkins 2012). Academics in peripheral countries experience the same difficulties, but from the higher education systems' point of view, western scholars can be assets able to perform roles in which they cannot be 
replaced by a highly skilled local employee. The most widespread example is copy editing in their native language. Thus, Slovakia, for some academics, was also a kind of last resort. They had problems finding appropriate jobs at home or were not admitted to $\mathrm{PhD}$ programs in other countries (not necessarily their country of origin). The story of John is emblematic. Once he got his PhD from an American university, he could not find any academic post. The only option was a part-time contract with high teaching loads and no time for research. For this reason, he decided to look for international job openings.

They [family] were happy I got the job [laughing] ... more than anything. My sister and her husband are also academics, so they have an understanding. My brother is actually surprisingly excited because we wanted to come to visit. I think my dad was slightly disappointed it wasn't something like the Philippines or Spain. Somewhere warm. They were pretty happy that I've got the job and the idea of being in Europe (...) When I first got the job and I realized I didn't know where the Bratislava was...I started on Google Maps and I realized when I was and I just started laughing. So my attitude was even if this job is awful, this is incredible as far as I able to see things and travel (Male, Westerner, HSS, INT5).

Many other people also openly admit that a lack of options in their home country was the major motivation for their emigration.

I became very pragmatic in my carrier, because I tried to get a professorship but I failed. To find a good position or fixed position is difficult in [Western Country]. So, I was looking around what I could do and a colleague told me they had this program (Male, Westerner, HSS, INT27).

And I applied for many, many scholarships in the EU. (...) They did accept me but I was put on the waiting list. So the [institution] said 'we have some money over for Hungary and for Slovakia because everyone wants to go to Poland and Czech Republic' (...) So I ended up as a masters student here. Then I applied for a PhD and then basically when I graduated I got a job here (Male, Easterner, HSS, INT7).

I was a PhD student in [city abroad]. But it's worth noting I did not have a scholarship, so on the one hand nobody wanted anything from me, and on the other I had to make a living (...) And at the end of this scholarship in Slovakia, I was offered a half time and then full time contract. This was before I defended my PhD thesis (...). However, the decision to accept the job was very simple, because in [city] no one had offered me a job (Male, Central Europe, HSS, INT33) 
Alexander (INT8) relocated to Slovakia as a second-choice country after being denied scholarship in another Central European country. Although his situation is similar to the story of Denis (INT7), for him it also presented a private problem, as he was forced to live apart from his girlfriend. In his life trajectory, the family situation conflicted with the lack of professional opportunities.

When I was finishing my studies in [home country] I was trying to decide what to do next... And my girlfriend at the moment was living in [another Central European country]. So I was thinking maybe I can try to find a master's program in [that country]. So I applied for [scholarship] but I didn't receive the scholarship for [city] and they told me... 'we have some spare spaces for Slovakia and Hungary'. So I thought that Hungarian language is really though so I thought I'll never learn it, so I decided to try and study in Slovakia (Male, Easterner, HSS, INT8).

Last resort scholars are the most characteristic employees of peripheral academic systems. In the "western" version, they were usually unable to find or keep their academic post in the academic system that trained them. In the "eastern" version, Slovakia was a EU (and thus livable) country available for them. In both cases, they would have worked elsewhere if there had been such an opportunity. This is the antithesis of enthusiasts, who are attracted by the country itself or its culture. This research shows that semi-peripheries are populated with the last-resort scholars rather than local enthusiasts. While the enthusiasts are present in core countries (see e.g. Siegert 2011; Tremblay's at al. 2014), it is unlikely that international last resort scholars find many positions there.

\section{Discussion}

The typology embraces six types of foreign-born academics in Slovakia: family-tied academics, commuters, socioeconomic migrants, transnational scholars, local enthusiasts, and last resort scholars. This typification helps to understand the diversity of the foreign-born scholars population in Slovakia and - if there is a need to attract foreigners to a semi-peripheral region - tailor specific incentives for each of these categories.

Table 1 summarizes the six types of academic migrants. When we take into account two factors - interest in Slovakia (as opposed to lack of particular interest in Slovakia) and primary motivation (financial or non-financial), we get a $2 \times 2$ scheme. Slovakia was interesting in and of itself or as a part of the $\mathrm{EU}$, for both commuters and economic migrants. In the case of transnational scholars and last resort scholars, as we have seen, geographical location was 
rather unimportant. On the other hand, enthusiasts and family-tied academics were relatively uninterested in financial conditions. It is worth emphasizing, however, that this table was constructed for demonstrative reasons only, as some types overlap: it is possible to be both enthusiast and a last-resort scholar or a commuter and simultaneously a transnational scholar. Nevertheless, the most important finding from this table is that the only empty cell is for those motivated by non-financial factors and not particularly interested in Slovakia. It means that Slovakia, similar to other peripheral regions, is not appealing for scholars who do not happen to be enthusiasts. On the other hand, the other cells indicate some advantages remain untapped due to lack of clear policies and sources of information, which need to be studied separately.

Table 1: Main types of foreign-born academics in Slovakia

\begin{tabular}{llll}
\hline & & Interest in Slovakia & \\
\cline { 3 - 3 } & & Particular interest & Lack of particular interest \\
& Financial factors & Commuters & Transnational scholars \\
Main & & Socioeconomic migrants & Last resort scholars \\
motivation & Non-financial factors & Enthusiasts & \\
& & Family-tied academics & \\
\hline
\end{tabular}

The proposed categories help capture typical traits of foreign-born academics employed in Slovakia. Two main axes: financial vs. non-financial motivations and particular interest vs. lack of it ${ }^{15}$ can be applied to other types of highly skilled migrants in CEE. Nevertheless, the categories themselves will certainly be different. For instance, in another research context, there should occur a category of delegated employees coming to Slovakia without special interest and without financial benefits, even if some of those corporate "birds of passage" can count on additional "relocation" money. These considerations go far beyond the scope of this paper. It is worth noting that there are also obvious differences between academic and non-academic migration. For instance, while academic migration is always voluntary, in the corporate world it is possible to relocate an employee who never really wanted to be transferred. Moreover, corporate contracts are usually fixed term and it is easier to come back to other company branches than it is for scholars to return to prior posts. In this light, the "fixed" vs. "permanent" dimensions seem relevant. Furthermore, there will be differences in highly skilled mobility across the EU.

\footnotetext{
15 This category may seem problematic because for some Slovakia is interesting as a part of the EU not a country itself. In this respect Western countries would be even more appealing, if they would be real. Nevertheless, migrants motivated by any trait of Slovakia as a country (be that cultural heritage or political membership) are different from those who would work everywhere because of very limited job opportunities (last resort scholars) and transnational scholars for whom the place is not of a major importance et all. Socioeconomic migrants usually had a job in their home country (unlike last resort scholars) and are interested in local working conditions (unlike transnational scholars - scholarship holders).
} 
One of them is the presence of commuters, who might be one of the core categories in CEE but are rare in Western Europe.

Table 1 shows one possible way of sorting categories from the typology. Another was a presence of bonds with institutions located abroad. Commuters had such connections solely by virtue of being employed in two places simultaneously. Transnational scholars also can possess international bonds because of their career history. In contrast, last resort scholars and economic migrants can be referred to as "settled migrants" because they acted as local scholars and international cooperation was rarely one of their concerns. Enthusiasts, in turn, can be found in both groups.

Table 2: Push and pull factors

\begin{tabular}{|c|c|c|c|c|c|c|c|}
\hline & & Commuters & $\begin{array}{l}\text { Enthu- } \\
\text { siasts }\end{array}$ & $\begin{array}{l}\text { Family-ties } \\
\text { academics }\end{array}$ & $\begin{array}{c}\text { Last } \\
\text { resort } \\
\text { scholars }\end{array}$ & $\begin{array}{l}\text { Socio- } \\
\text { economic } \\
\text { migrants }\end{array}$ & $\begin{array}{l}\text { Transna- } \\
\text { tional } \\
\text { scholars }\end{array}$ \\
\hline \multirow{4}{*}{ 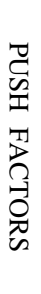 } & $\begin{array}{l}\text { Bad economy in a } \\
\text { sending country }\end{array}$ & - & - & - & - & + & - \\
\hline & $\begin{array}{l}\text { Corruption and political } \\
\text { instability in a sending } \\
\text { country }\end{array}$ & - & - & - & - & + & - \\
\hline & $\begin{array}{l}\text { Insufficient salary in a } \\
\text { sending country }\end{array}$ & + & - & - & - & + & - \\
\hline & Lack of other job offers & - & - & - & + & - & - \\
\hline \multirow{5}{*}{ 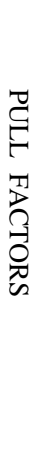 } & $\begin{array}{l}\text { Genuine interest in } \\
\text { Slovakia - its cultural } \\
\text { heritage or political } \\
\text { system }\end{array}$ & - & + & - & - & - & - \\
\hline & $\begin{array}{l}\text { Interest in a particular } \\
\text { research team or } \\
\text { institution }\end{array}$ & - & + & - & - & - & + \\
\hline & $\begin{array}{l}\text { Relationships with } \\
\text { Slovak citizens }\end{array}$ & - & - & + & - & - & - \\
\hline & $\begin{array}{l}\text { Less severe } 2008 \text { crisis } \\
\text { in Slovakia }\end{array}$ & - & - & + & - & - & - \\
\hline & $\begin{array}{l}\text { European scholarship } \\
\text { schemes }\end{array}$ & + & + & - & - & - & + \\
\hline
\end{tabular}

From the sociological perspective, it is vital to distinguish between push and pull factors (Table 2) associated with the decisions of all six groups of migrants. The empirical material allows us to discuss four push and five pull factors. Push factors (bad economy, political instability, insufficient salary, lack of job offers) usually impacted socioeconomic migrants, last resortscholars and - to the lesser extent - commuters. Pull factors (interest in Slovakia or a particular institution, relationship with a Slovak, mild 2008 crisis symptoms, a scholarship opportunity) were more typical for the biographies of 
enthusiasts, family-tied academics, and transnational scholars. It is symptomatic that none of those can be easily manipulated, both in the case of microstructural and macrostructural factors. For instance, family-tied academics were people who decided to move to Slovakia because of a Slovak partner, his or her social capital, education, or property (microstructural factors). Their decision was often encouraged by a macrostructural factor: less severe financial crisis. This shows that migration to Wallersteinian peripheries is largely independent of higher education policy. Among the pull factors, only one can be influenced by the policymakers - the scholarship schemes, most notably the ones co-financed by the EU and offering a decent salary. It is a strong trigger for transnational scholars but also commuters and enthusiasts. The problem is that such activities attract academics for a fixed time. When the financing is over, they will go to the next country. This is another circumstance showing that the global academic system uses peripheries instrumentally (see e.g. Connell et al. 2017). International scholars visit the country, use its resources and then just move further without any obligation, and with a limited sense of belonging to a local academic world.

\section{Conclusion}

By comparing the results of this study with the results of foreign studies, we can try to highlight differences between the motivations of academics employed in the Slovak academic system and elsewhere in the world. Financial factors are reported to be important, although not a primary motivation, for internationally mobile academics in cross-country comparisons (Franzoni et al. 2012: 10). Highly educated people migrate even though in western economies they are overrepresented in fixed-time employment and underrepresented in managerial positions (see e.g. Aldén - Hammarstedt 2014: 13). Slovakia does not offer good academic salaries and what makes it even more different from western countries is the widespread phenomenon of holding multiple jobs. In order to get additional money, some local scholars teach or do research at more than one institution. The cultural pattern of having two jobs at a time also accounts for the occurrence of commuting scholars, a marginal category in western Europe. Another important thing is a relatively narrow scope of the international engagement of foreign-born scholars in Slovakia compared to western countries (Lawson et al. 2018) - they often do not build any bridges and, due to family situation and long-term employment, resemble Slovak scholars in their habits and expectations. The prevalence of last-resort scholars, family-tied academics and commuters demonstrates that motivations of foreign-born scholars in semi-peripheries are very different from those who migrate to one of the central countries. 
This comparison shows a different face of internationalization, which unlike the American case (Corley - Sabharwal 2007) does not always imply the improvement of research quality (Ortiga et al. 2017). Wallersteinian centers are still brain-draining peripheries and the presence of foreign talent in the peripheries is rather an effect of push factors (lack of professional opportunities at home, unstable political situation) and various private reasons (family connection, easiness of commuting). This makes Western conceptualizations of highly-skilled migrants and mobile academics partially invalid in this part of the world.

Kamil Luczaj is an Assistant Professor at University of Information Technology and Management in Rzeszow, Poland. His research focuses on migration studies and the sociology of culture. Currently, he is a PI of the project titled "Foreign-Born Scholars in Poland: motivations, life trajectories, and academic potential" sponsored by the Polish Ministry of Higher Education.

\section{REFERENCES}

ALATAS, S. F., 2003: Academic Dependency and the Global Division of Labour in the Social Sciences. Current Sociology 51, pp. 599-613.

ALBERTS, H. C., 2008: The Challenges and Opportunities of Foreign-Born Instructors in the Classroom. Journal of Geography in Higher Education 32, no. 2: 189-203.

ALDÉN, L. - HAMMARSTEDT, M., 2014: Integration of Immigrants on the Swedish Labour Market - Recent Trends and Explanations. Accessible: https://lnu.se/contentassets/729bb815ca184ffc9d1c33192c8b9a55/lmdswp20149_m all.pdf [1.10.2018].

ARBESMAN, S. - WILKINS, J., 2012: The Rise of Fractional Scholarship. Ewing Marion Kauffman Foundation. 10.2139/ssrn.2048780.

BAHNA, M., 2018: Study Choices and Returns of International Students: On the Role of Cultural and Economic Capital of the Family, Population, Space and Place 24(2) (Online first).

BENSON, M., 2016: Deconstructing Belonging in Lifestyle Migration: Tracking the Emotional Negotiations of the British in Rural France. European Journal of Cultural Studies, Vol 19, Issue 5, pp. 481-494.

BENSON, M. - O'REILLY, K., 2009: Migration and the Search for a Better Way of Life: A Critical Exploration of Lifestyle Migration. The Sociological Review 57, 4: 608-625.

BLAZEK, M., 2015: Labour Exploitation of Non-EU Migrants in Slovakia: Patterns, Implications and Structural Violence. In: Waite, L. et al. (eds.) Vulnerability, Exploitation and Migrants: Insecure Work in a Globalised Economy. London: Palgrave Macmillan, pp. 72-85.

CONNELL, R. - PEARSE, R. - COLLYER, F. - MAIA, J. - MORRELL, R., 2017: Negotiating with the North: How Southern-Tier Intellectual Workers Deal with the Global Economy of Knowledge. The Sociological Review, OnlineFirst. 
CORLEY, E. - SABHARWAL, M., 2007, Foreign-Born Academic Scientists and Engineers: Producing More and Getting Less than their U.S.-Born Peers? Research in Higher Education 48(8):909-940.

FRANZONI, Ch. - SCELLATO, G. - STEPHAN, P., 2012, Foreign-Born Scientists: Mobility Patterns for 16 Countries. Nature Biotechnology 30: 1250-1253.

GUEST, G. - MACQUEEN, K. - NAMEY, E., 2012: Applied Thematic Analysis, Thousand Oaks: Sage.

HLINČÍKOVÁ, M., 2010: Sonda do života migrantov z Vietnamu. In: J. Filadelfiová, O. Gyárfášová, M. Hlinčíková, M. Sekulová: Sondy do kultúrnej diverzity na Slovensku, Bratislava: IVO, pp. 45-66.

IREDALE, R., 2001: The Migration of Professionals: Theories and Typologies. International Migration. 39: 7-26.

IREDALE, R., 2016: High-Skilled Migration. In: Reed Ueda, Encyclopedia of Migration. Living Edition, available: https://link.springer.com/reference workentry/10.1007\%2F978-94-007-6179-7_12-1 [8 May 2018].

KREBER, C. - HOUNSEL, J., 2014: Being an International Academic: A Phenomenological Study of Academic Migrants Adjusting to Working and Living in Scotland. In: N. Maadad, M. Tight (Eds.), International Perspectives on Higher Education Research, pp. 17-41. Bingley: Emerald.

LÁŠTICOVÁ, B., 2014: New Media, Social Capital and Transnational Migration: Slovaks in the UK. Human Affairs 24: 406-422.

LAU, T., 2009: Transnational Anthropologies: Producing Knowledge in the Emerging Global Academy, Anthropology News 50: 7-8.

LAWSON, C. - SALTER, A. - HUGHES, A. - KITSON, M., 2018: Citizens of Somewhere: The Geography of Foreign and Native-Born Academics' External Engagement. Paper presented at DRUID18. Copenhagen Business School, Copenhagen, Denmark, accessible: https://conference. druid.dk/acc_papers/pwhnlhtt3d61a42ata7qjtktb5tdpv.pdf [1 Oct 2018]. June 11-13, 2018

MAXIMOVA-MENTZONI, T. - EGELAND, C. - ASKVIK, T. - DRANGE, I. STØREN, L. - RØSDAL, T. - VABØ, A., 2016: Being a Foreigner is no Advantage Oslo i Akershus: Work Research Institute.

McKINNEY, J., 1969: Typification, Typologies, and Sociological Theory. Social Forces48: 1-12.

MINARECHOVÁ, R., 2017: Fewer Worries for Slovakia's “Aliens”? The Slovak Spectator 21 Dec 2017, accessbile: https://spectator.sme.sk/c/20724640/fewer-worries-forslovakias-aliens.html\#paid-content-before [2 May 2018].

MUCHA, J. - ŁUCZAJ, K., 2017: Developing the Academic Careers of Foreign Scholars in Poland: The Case of Krakow. Central and Eastern European Migration Review 6(2): 141-162.

MYERS, P., 2004: Max Weber: Education as Academic and Political Calling Author(s): Perry Myers. German Studies Review 27: 269-288.

OECD, 2017: Economic Surveys: Slovak Republic 2017. Paris: OECD Publishing.

MUNENE, I. I., 2014: Outsiders within: Isolation of International Faculty in an American University. Research in Post-Compulsory Education 19:4: 450-467.

PIEKUT, A., 2013: You've got Starbucks and Coffee Heaven... I Can Do This! Spaces of Social Adaptation of Highly Skilled Migrants in Warsaw. Central and Eastern European Migration Review 2, 1: 113-134. 
RAGHURAM, P., 2004: The Difference that Skills Make: Gender, Family Migration Strategies and Regulated Labour Markets. Journal of Ethnic and Migration Studies 30:2: 303-332.

SCHÜTZE, F., 2014: Autobiographical Accounts of War Experiences. Qualitative Sociology Review 10: 224-283.

SEKULOVÁ, M., 2010: Objavovanie nových obzorov - pracovná migrácia z Rumunska. In: J. Filadelfiová, O. Gyárfášová, M. Hlinčíková, M. Sekulová, Sondy do kultúrnej diverzity na Slovensku. Bratislava: IVO, pp. 15-44.

SIEGERT, A., 2011: On Socialization, Patriotism and Trust: The Migration of HomewardBound Russian Academics. Nationalities Papers 39, 6: 977-995.

SKACHKOVA, P., 2007: Academic Careers of Immigrant Women Professors in the U.S. Higher Education 53: 697-738.

SMITH, K. B., 2002: Typologies, Taxonomies, and the Benefits of Policy Classification. Policy Studies Journal 3: 379-395.

STACEY, J., 1998: Brave New Families: Stories of Domestic Upheaval in Late-TwentiethCentury America. University of California Press: Berkeley-Los Angeles-London.

ORTIGA, Y. - CHOU, M-H. - SONDHI, G. - WANG, J., 2017: Academic "Centres," Epistemic Differences and Brain Circulation. International Migration 56: 90-105.

OZPS, 2017: Odborový zväz pracovníkov školstva a vedy na Slovensku. Počet zamestnancov a priemerné platy $\mathrm{v}$ regionálnom školstve a na verejných vysokých školách I. polrok 2017. https://www.ozpsav.sk/files/mzdy_i_polrok_2017.pdf.

PAUWELS, A., 2014: The Teaching of Languages at University in the Context of SuperDiversity. Journal International Journal of Multilingualism 11.

RODRIGUEZ, M. L., 2014: Centers and Peripheries in Knowledge Production, Routledge: New York-London.

ROSTAN, M. - HÖHLE, E., 2014: The International Mobility of Faculty. In: F. Huang et al. (eds.): The Internationalization of the Academy. The Changing 79 Academy - The Changing Academic Profession in International Comparative Perspective 10: 79-104.

TILLEY, S. - TAYLOR, L., 2014: Complicating Notions of "Scholar-Activist" in a Global Context: A Discussion Paper. Journal of the International Society for Teacher Education 18: 53-62.

VUIN, A. - CARSON, D. - CARSON, D. - GARRETT, J., 2016: The Role of Heritage Tourism in Attracting "Active" In-Migrants to "Low Amenity" Rural Areas. Rural Society 25:2: 134-153.

WEBER, M., 2004: The Vocation Lectures: Science as a Vocation \& Politics as a Vocation. Indianapolis: Hackett Publishing Company.

WRIGHT, E. O., 1997: Class Counts: Comparative Studies in Class Analysis. Cambridge: Cambridge University Press.

TREMBLAY, R. - HARDWICK, S. - O'NEILL, J., 2014: Academic Migration at the Canada - US Border. American Review of Canadian Studies 44: 118-134.

XU, Y., 2014, Becoming Researchers: A Narrative Study of Chinese University EFL Teachers' Research Practice and their Professional Identity Construction. Language Teaching Research 18: 242-259.

ZOMMERS, Z. - McDONALD, D. W., 2012: Protected Areas as Frontiers for Human Migration. Conservation Biology 26: 547-556. 